\title{
Effects of theophylline, dexamethasone and salbutamol on cytokine gene expression in human peripheral blood CD4+ T-cells
}

\author{
D.K.L. Choy*, F. Ko*, S.T. Li*, L.S. Ip*, R. Leung*, D. Hui*, K.N. Lai**, C.K.W. Lai*
}

\begin{abstract}
Effects of theophylline, dexamethasone and salbutamol on cytokine gene expression in human peripheral blood CD4+ T-cells . D.K.L. Choy, F. Ko, S.T. Li, L.S. Ip, R. Leung, D. Hui, K.N. Lai, C.K.W. Lai. C)ERS Journals Ltd 1999.

ABSTRACT: CD4+ T-cells are considered as pivotal in orchestrating the airway inflammation in asthma through the actions of their cytokines. Current hypothesis suggests that the anti-asthma effect of theophylline may be due to its anti-inflammatory actions, although the exact mechanisms remain unclear.

The in vitro effect of theophylline on cytokine gene expression in peripheral blood CD4+ T-cells in normal subjects was compared with that of dexamethasone and salbutamol. CD4+ T-cells were cultured with phytohaemagglutin and phorbol myristate acetate in the presence of different concentrations of theophylline $\left(10^{-8}-10^{-3} \mathrm{M}\right.$ or $\left.0.0018-180 \mu \mathrm{g} \cdot \mathrm{mL}^{-1}\right)$ in one group of subjects $(\mathrm{n}=8)$, dexamethasone $\left(10^{-9}-10^{-6} \mathrm{M}\right.$ or $\left.0.39-390 \mathrm{ng} \cdot \mathrm{mL}^{-1}\right)$ in a second group $(\mathrm{n}=8)$ and salbutamol $\left(10^{-9}-10^{-4} \mathrm{M}\right.$ or $0.00058-58$ $\left.\mu \mathrm{g} \cdot \mathrm{mL}^{-1}\right)$ in a third group (n=8). Gene expression of interleukin (IL)-3, IL-4, IL-5, granulocyte-macrophage colony-stimulating factor (GM-CSF) and interferon (IFN)- $\gamma$ was semiquantified by reverse transcription-polymerase chain reaction.

Suppressed expression of IL-3 (36.9\%), IL-4 (38.8\%), GM-CSF (24.6\%) and IFN- $\gamma$ $(37.7 \%)$, but not of IL-5, was only seen with theophylline at a concentration of $10^{-3} \mathrm{M}$ $\left(180 \mu \mathrm{g} \cdot \mathrm{mL}^{-1}\right)(\mathrm{p}<0.05)$ and not at lower concentrations. In contrast, dexamethasone caused a dose-dependent suppression of transcription of all cytokines, with $39.5 \%$ for IL-3, 84.4\% for IL-4, 40.6\% for IL-5, 50.9\% for GM-CSF and $31.8 \%$ for IFN- $\gamma$ at $10^{-6} \mathrm{M}$ $\left(390 \mathrm{ng} \cdot \mathrm{mL}^{-1}\right)(\mathrm{p}<0.05-0.001)$. Salbutamol did not suppress gene expression of any of the cytokines at the concentrations examined.

These data suggest that cytokine gene expression of CD4+ T-cells is not affected at therapeutic concentrations of theophylline and salbutamol, but its suppression is likely to be an important mechanism underlying the therapeutic effect of corticosteroids in asthma.

Eur Respir J 1999; 14: 1106-1112.
\end{abstract}

*Dept of Medicine, Prince of Wales Hospital, Chinese University of Hong Kong. **Dept of Medicine, Queen Mary Hospital, University of Hong Kong.
Correspondence: C. Lai
C/O Dept of Medicine
Prince of Wales Hospital
Shatin, N.T.
Hong Kong
Fax: 85226489957

\section{Keywords: Asthma}

corticosteroids

cytokines

salbutamol

theophylline

\section{Received: November 101998}

Accepted after revision July 171999

This study was supported by the RGC Grant CUHK 386/95M

It is now well recognized that asthma is closely associated with airway inflammation, even in patients with mild disease [1]. One of the most consistent inflammatory changes in the asthmatic airway is infiltration by activated lymphocytes, eosinophils and mast cells $[1,2]$. Current evidence suggests that T-lymphocytes are pivotal in orchestrating this inflammatory response through the release of T-helper (Th)-2 cytokines from CD4+ cells [3].

Recognition of the inflammatory basis of asthma has led to the recommendation of early use of anti-inflammatory agents by a number of national and international guidelines of asthma management [4]. Amongst the anti-inflammatory agents, corticosteroids are by far the most effective in controlling asthma. Although the exact mechanisms underlying their therapeutic efficacy remain unclear, a study on bronchial biopsies in asthmatics have shown that corticosteroids may act by modulation of cytokine expression with consequent inhibition of the local bronchial inflammatory infiltrate and tissue eosinophilia [5]. T-lymphocytes, particularly the CD4+ cells, are a rich source of pro-inflammatory cytokines in asthma. Suppresion of the expression of these cytokines, e.g. interleukin (IL)-5 and granulocyte-macrophage colony-stimulating factor (GMCSF), by corticosteroids has been shown in asthmatics recovering from acute exacerbation of their disease [6-8].
Theophylline is a medication which has been used in the treatment of bronchial asthma for $>50$ yrs. Whilst traditionally theophylline has been regarded as a bronchodilator, there is now growing evidence to suggest it possesses anti-inflammatory properties even at subtherapeutic levels [9-11]. Indeed, several studies have demonstrated that xanthines may exert their anti-inflammatory and immunomodulatory effects by the inhibition of eosinophil degranulation [12], histamine release from mast cells and basophils [13] antigen- and mitogen-induced T-cell proliferation [14] and T-cell recruitment into the bronchial mucosa [10], and the generation of cytokines [15]. However, the current knowledge concerning its anti-inflammatory mechanisms remains nondefinitive. This study, aimed to further define the actions of theophylline by comparing their effects on cytokine gene expression of peripheral blood CD4+ T-cells with that of dexamethasone and salbutamol.

\section{Methods}

Subjects

Three groups of nonsmoking subjects were studied. All were normal healthy volunteers with no prior use of any 
anti-asthmatic medications. Informed consent was obtained from each subject. Peripheral venous blood samples were taken once from all 24 subjects.

\section{Isolation of $\mathrm{CD} 4+$ cell subset}

Peripheral blood mononuclear cells (PBMCs) separated by Isopaque-Ficoll (Lymphoprep; Nycomed AS, Oslo, Norway) density gradient centrifugation were washed with phosphate buffered saline (PBS), and then resuspended in culture medium consisting of Roswell Park Memorial Institute (RPMI) 1640 medium (Gibco, Chagrin Falls, NY, USA) supplemented with $10 \%$ heat-inactivated foetal bovine serum (FBS; Gibco), L-glutamine (2 mM), penicillin) $\left.100 \mathrm{U} \cdot \mathrm{mL}^{-1}\right)$ and streptomycin $\left(100 \mu \mathrm{g} \cdot \mathrm{mL}^{-1}\right)$. Magnetizable polystyrene beads coated with monoclonal antibody (MoAb) specific for CD4 (Dynal AS, Oslo, Norway) were used to select CD4+ T-cells from PBMCs as described previously [16]. CD4+ T-cells were 99.8 $0.02 \%$ (mean $\pm \mathrm{SD})$ pure as assessed by flow cytometry (EPICS; Coulter Corporation, Miami, FL, USA) using fluorescin conjugated anti-human Leu-3A MoAb (Becton Dickinson, Mountain View, CA, USA). Immunofluorescence microscopy revealed that these CD4+ cells were also CD3 positive but were negative for CD11b. Cell viability was $>98 \%$ as determined by the trypan blue dye exclusion test.

\section{Culture of CD4+ cells}

Isolated CD4+ cells, adjusted to $1 \mathrm{~mL}$ aliquots of $1 \times$ $10^{6}$ cells, were dispended into 48 -well culture plates. The cells were incubated at $37^{\circ} \mathrm{C}$ for $6 \mathrm{~h}$ in a humidified atmosphere with $5 \% \mathrm{CO}_{2}$ in the presence of phytohaemagglutinin $\left(10 \mu \mathrm{g} \cdot \mathrm{mL}^{-1}\right)$ and phorbol myristate acetate $\left(0.5 \mathrm{ng} \cdot \mathrm{mL}^{-1}\right)$. It has been shown in previous studies that these concentrations induced maximal cytokine production with lowest toxicity $[16,17]$. To study the effects of theophylline, dexamethasone and salbutamol on cytokine gene expression of these CD4+ T-cells, theophylline was added at concentrations of $10^{-8}-10^{-3} \mathrm{M}(0.0018-$ $\left.180 \mu \mathrm{g} \cdot \mathrm{mL}^{-1}\right)$ to the cell cultures in the first group of subjects $(n=8)$, dexamethasone at $10^{-9}-10^{-6} \mathrm{M}(0.39-390$ $\left.\mathrm{ng} \cdot \mathrm{mL}^{-1}\right)$ in the second group of subjects $(\mathrm{n}=8)$, and salbutamol at $10^{-9}-10^{-4} \mathrm{M}\left(0.00058-58 \mu \mathrm{g} \cdot \mathrm{mL}^{-1}\right)$ in the third group of subjects $(n=8)$. These particular concentrations were chosen to cover the normal therapeutic concentrations of these medications in vivo. Theophylline and dexamethasone were dissolved in water while salbutamol was dissolved in dimethylsulphoxide $0.005 \%$. In a pilot study, solvents were used only as controls and no effect on cytokine gene expression was found.

\section{Preparation of total ribonucleic acid}

A microadaptation of the guanidinium thiocyanate/cesium chloride procedure was used to prepare total ribonucleic acid (RNA) from CD4+ cells [18]. All RNA samples prepared from $1 \times 10^{6}$ cells were dissolved in $20 \mu \mathrm{L}$ diethylpyro-carbonate-treated (DEPC- $\left.\mathrm{dH}_{2} \mathrm{O}\right)$ and were stored at $-70^{\circ} \mathrm{C}$ until assay. The quantity of RNA was checked by formaldehyde agarose gel electrophoresis and measured by spectrophotometry. Two microlitres of total RNA contained $\sim 0.1 \mu \mathrm{g}$ RNA.

\section{Oligonucleotide primers}

Specific primers for IL-3, IL-4, IL-5, GM-CSF, interferon (IFN)- $\gamma$ and reduced glyceraldehyde 3-phosphate dehydrogenase (GAPDH) were obtained from Clontech (Palo Alto, CA, USA). The sequences and related information are shown in table 1.

\section{Detection of cytokine gene expression by polymerase chain reaction}

Gene expression for the cytokines was studied in CD4+ cells using the GeneAmp RNA polymerase chain reaction (PCR) kit (Perkin Elmer Cetus, Norwalk, CT, USA). Messenger ribonucleic acid (mRNAs) of each sample was first reverse transcribed into complimentary deoxyribonucleic acid (cDNAs), which in turn was subjected to PCR amplification using specific primers. In brief, first-strand deoxyribonucleic acid (DNA) was synthesized in a final volume of $20 \mu \mathrm{L}$ with the following components: $2 \mu \mathrm{L}$

Table 1. - Primers used in polymerase chain reaction

\begin{tabular}{|c|c|c|c|}
\hline Cytokine & Primer sequences & $\begin{array}{l}\text { PCR product } \\
\text { bp }\end{array}$ & $\begin{array}{c}\text { Concentration used } \\
\mu \mathrm{M} \cdot \mathrm{PCR}^{-1}\end{array}$ \\
\hline \multirow[t]{2}{*}{ IL-3 } & 5'ATGAGCCGCCTGCCCGTCCTG & 449 & 0.15 \\
\hline & 5'GTTGTCTGCTGAAATCGGAGCG & & \\
\hline \multirow[t]{2}{*}{ IL-4 } & 5'ATGGGTCTCACCTCCCAACTGCT & 456 & 0.5 \\
\hline & 5'ТАСТСТСТСТСТTТАТАAGTTTCACAAGC & & \\
\hline \multirow[t]{2}{*}{ IL-5 } & 5'GCTTCTGCATTTGAGTTTGCTAGCT & 293 & 0.5 \\
\hline & 5'GAATTATTTCTTTATGTAACTGCCGGT & & \\
\hline \multirow[t]{2}{*}{ GM-CSF } & 5'ATGTGGCTGCAGAGCCTGCTGC & 424 & 1 \\
\hline & 5'TACGACAAAGCTCCAGCTTCTCGTAG & & \\
\hline \multirow[t]{2}{*}{ IFN- $\gamma$} & 5'ATGAAATATACAAGTTATATCTTGGCTTT & 494 & 1 \\
\hline & 5'TACGACAAAGCTCCAGCTTCTCGTAG & & \\
\hline \multirow[t]{2}{*}{ GAPDH } & 5'TGAAGGTCGGAGTCAACGGATTTGGT & 983 & 0.05 \\
\hline & 5'CACCACCTGGAGTACCGGGTGTAC & & \\
\hline
\end{tabular}

PCR: polymerase chain reaction; IL: interleukin; GM-CSF: granulocyte-macrophage colony-stimulating factor; IFN: interferon; GAPDH: glyceraldehyde 3-phosphate dehydrogenase. 
total RNA in DEPC- $\mathrm{dH}_{2} \mathrm{O}, 2.5 \mathrm{mM}$ 16-oligomer of thymidine deoxynucleotide (Oligo d (T)), $5 \mathrm{mM} \mathrm{MgCl} 2,10$ $\mathrm{nM}$ Tris-HCL buffer, $\mathrm{pH} 8.3,50 \mathrm{mM} \mathrm{KCl}, 1 \mathrm{mM}$ dNTP, and $10 \mathrm{U}$ of ribonuclease (RNase) inhibitor. The mixture was incubated in a Perkin-Elmer Cetus DNA Thermal Cycler at $42^{\circ} \mathrm{C}$ for $30 \mathrm{~min}$ followed by $5 \mathrm{~min}$ at $99^{\circ} \mathrm{C}$ and flash cooling to $4^{\circ} \mathrm{C}$. The resulting cDNA $(10 \mu \mathrm{L})$ was mixed separately either with $2 \mathrm{mM} \mathrm{MgCl}_{2}, 10 \mathrm{mM}$ Tris$\mathrm{HCl}$ buffer, $50 \mathrm{mM} \mathrm{KCl}$, IL-3 IL-4 IL-5, GM-CSF, or (IFN)- $\gamma$ specific PCR primers, GAPDH primer, $1.25 \mathrm{U}$ AmpliTaq DNA polymerase, and $0.074 \mathrm{~Bq}\left[\alpha-{ }^{32} \mathrm{P}\right]$-deoxycytidine triphosphate (dCTP) in a final volume of 50 $\mu \mathrm{L}$. Amplification was started with 2 min denaturation at $94^{\circ} \mathrm{C}$ followed by 30 PCR cycles. Each cycle consisted of $1 \mathrm{~min}$ at $94^{\circ} \mathrm{C}$ for denaturation, $1 \mathrm{~min}$ at $62^{\circ} \mathrm{C}$ for annealing, and $1 \mathrm{~min}$ at $72^{\circ} \mathrm{C}$ for extension. The final extension lasted $10 \mathrm{~min}$ at $72^{\circ} \mathrm{C}$ in all instances. The experimental condition and number of cycles of PCR were predetermined to ensure the amount of cytokine and "housekeeping" gene (GAPDH) fragments were in the linear range of amplification. The efficiency of cDNA synthesis was controlled using control cRNA (IL-1 $\alpha$ RNA from plasmid pAW109 (pAW109 provided by Clontech) in every reaction.

Negative controls for PCR consisted of: samples in which the reverse transcriptase was omitted to detect any contamination by genomic cDNA; and a reagents control in which RNA was replaced by DEPC- $\mathrm{dH}_{2} \mathrm{O}$. Positive control DNAs were obtained from Clontech Laboratory.

Agarose gel electrophoresis and semiquantitation of polymerase chain reaction products

The PCR mixture $(20 \mu \mathrm{L})$ was added to $5 \mu \mathrm{L}$ of loading dye mixture and electrophoresed in a $90 \mathrm{~V}$ constant voltagefield in $1.7 \%$ agarose (Sigma, St Louis, MO, USA) containing ethidium bromide until the bromophenol blue dye front had migrated for a distance of $6 \mathrm{~cm}$. Haemophilus aegyptius (Hae)III-digested ФX174 DNA (Gibco) was used to determine the size of the PCR products. After electrophoresis, gel slices corresponding to the radioactive bands of the PCR product were excised and counted by liquid scintillation. ${ }^{32} \mathrm{P}$ incorporated into the PCR products of each of the cytokines was normalized with that of the amplified GAPDH PCR products as described previously [19]. The results were expressed as a ratio calcu- lated from the counts per minute (cpm) of amplified cytokine gene product over the cpm of amplified GAPDH PCR product.

\section{Statistical analysis}

All data are mean \pm SEM unless otherwise stated. The data (all nonparametric) were compared using Kruskal-Wallis followed by Mann-Whitney. All p-values of $<0.05$ were considered significant.

\section{Results}

The results of suppression of cytokine gene expression of CD4+ T-cells at various concentrations of theophylline, dexamethasone and salbutamol are presented in tables 2-4, respectively. The respective agarose gel electrophoreses are shown in figures $1-3$. Suppressed expression of IL3 (36.9\%), IL-4 (38.8\%), GM-CSF $(24.6 \%)$ and IFN- $\gamma$ $(37.7 \%)$, but not of IL-5, was only seen with theophylline at a high concentration of $10^{-3} \mathrm{M}\left(180 \mu \mathrm{g} \cdot \mathrm{mL}^{-1}\right)$ $(\mathrm{p}<0.05-0.01)$ and not at lower concentrations. In contrast, dexamethasone caused a dose-dependent suppression of transcription of all cytokines, with $39.5 \%$ for IL-3, $84.4 \%$ for IL- $4,40.6 \%$ for IL-5, $50.9 \%$ for GM-CSF and $31.8 \%$ for IFN- $\gamma$ at $10^{-6} \mathrm{M}\left(390 \mathrm{ng} \cdot \mathrm{mL}^{-1}\right) \quad(\mathrm{p}<0.05-$ 0.001 ). Salbutamol did not produce any significant effects on cytokine gene expression at therapeutic concentrations.

\section{Discussion}

Clinical studies have shown that both corticosteroids [1] and xanthines [9-11] possess anti-inflammatory properties, although the exact mechanisms underlying their therapeutic efficacy remain unclear. In this study, the effects of these agents on the gene expression of various proinflammatory cytokines secreted by CD4+ T-cells has been examined. Previous studies have demonstrated the importance of CD4+ T-cells and their cytokines in the pathogenesis of asthma [7, 8]. In vitro studies indicate that IL-3, IL-5 and GM-CSF can influence the production, maturation and activation of eosinophils [20], whilst IL-4 is thought to be important in the promotion of isotype switching of B cells towards immunoglobulin

Table 2. - Percentage inhibition of cytokine messenger ribonucleic acid (mRNA) expression of CD4+ cells by theophylline

\begin{tabular}{lcccccc}
\hline & \multicolumn{5}{c}{ Theophilline concentration $\mathrm{M}\left(\mu \mathrm{g} \cdot \mathrm{mL}^{-1}\right)$} \\
\cline { 2 - 7 } & $10^{-3}$ & $10^{-4}$ & $10^{-5}$ & $10^{-6}$ & $10^{-7}$ & $10^{-8}$ \\
& & $(18)$ & $(1.8)$ & $(0.18)$ & $(0.018)$ & $(0.0018)$ \\
\hline IL-3/GAPDH & $36.9 \pm 13.4^{*}$ & $23.2 \pm 7.0$ & $-22.8 \pm 25.4$ & $0.6 \pm 7.4$ & $2.1 \pm 13.7$ & $5.3 \pm 3.2$ \\
IL-4/GAPDH & $38.8 \pm 5.1^{*}$ & $16.5 \pm 5.6$ & $1.3 \pm 7.7$ & $9.2 \pm 8.7$ & $8.6 \pm 5.3$ & $14.6 \pm 5.4$ \\
IL-5/GAPDH & $9.5 \pm 6.5$ & $-23.2 \pm 18.8$ & $-15.1 \pm 6.3$ & $-11.2 \pm 12.8$ & $-1.1 \pm 11.7$ & $7.1 \pm 6.4$ \\
GM-CSF/GAPDH & $24.6 \pm 10.7^{*}$ & $20.5 \pm 6.4$ & $6.3 \pm 7.2$ & $12.8 \pm 10.4$ & $11.7 \pm 11.9$ & $6.4 \pm 8.6$ \\
IFN- $\alpha /$ GAPDH & $37.7 \pm 7.4^{*}$ & $12.9 \pm 18.2$ & $1.9 \pm 14.4$ & $-7.0 \pm 14.8$ & $-11.1 \pm 15.6$ & $-1.0 \pm 13.5$ \\
\hline
\end{tabular}

Data are mean \pm SEM. IL: interleukin; GAPDH: glyceraldehyde 3-phosphate dehydrogenase; GM-CSF: granulocyte-macrophage colony-stimulating factor; IFN: interferon. *: $\mathrm{p}<0.05$ versus phorbol myristate acetate (PMA)/phytohaemogglutinin (PMA) stimulation without theophylline; **: $\mathrm{p}<0.01$ versus phorbol myristate acetate (PMA)/phytohaemogglutining (PMA) stimulation without theophylline (Kruskal-Wallis followed by Mann-Whitney analysis). Values are calculated as 100\% - (cytokine expression with PHA/PMA and theophylline/cytokine expression with PHA/PMA only) $\times 100 \%$. 
Table 3. - Percentage inhibition of cytokine messenger ribonucleic acid (mRNA) expression of CD4+ cells by dexamethasone

\begin{tabular}{lcccc}
\hline & \multicolumn{4}{c}{ Dexamethasone concentration $\mathrm{M}\left(\mathrm{ng} \cdot \mathrm{mL}^{-1}\right)$} \\
\cline { 2 - 5 } & $10^{-6}$ & $10^{-7}$ & $10^{-8}$ & $10^{-9}$ \\
& $(390)$ & $(39)$ & $(3.9)$ & $(0.39)$ \\
\hline IL-3/GAPDH & $39.5 \pm 10.6^{*}$ & $38.0 \pm 8.5^{*}$ & $31.5 \pm 8.1^{*}$ & $8.4 \pm 7.4^{\#}$ \\
IL-4/GADPH & $84.4 \pm 2.7^{* * *}$ & $80.5 \pm 4.0^{* * *}$ & $66.1 \pm 2.9^{* * *}$ & $16.7 \pm 11.9^{* *}$ \\
IL-5/GADPH & $55.6 \pm 5.4^{* * *}$ & $54.5 \pm 5.3^{* * *}$ & $40.6 \pm 9.7^{* * *}$ & $21.2 \pm 9.6^{* *}$ \\
GM-CSF/GAPDH & $50.9 \pm 8.5^{* *}$ & $54.2 \pm 6.4^{* *}$ & $35.0 \pm 17.7^{*}$ & $11.9 \pm 11.1^{\$}$ \\
IFN- $\alpha$ /GAPDH & $31.8 \pm 13.1^{*}$ & $24.0 \pm 12.0$ & $25.5 \pm 10.3^{*}$ & $17.8 \pm 14.8$ \\
\hline
\end{tabular}

Data are mean \pm SEM. For definitions, see footnote to table $1 . *$ : $<<0.05$ versus PHA/PMA stimulation without dexamethasone; **: $\mathrm{p}<0.01$ versus PHA/PMA stimulation without dexamethasone; $* * *: \mathrm{p}<0.001$ versus PHA/PMA stimulation without dexamethasone; \#: $\mathrm{p}<0.05$ versus PHA/PMA stimulation with dexamethasone at concentrations of $10^{-6}-10^{-8} \mathrm{M} ;: \mathrm{t}<0.001$ versus PHA/PMA stimulation with dexamethasone at concentrations of $10^{-6}-10^{-8} \mathrm{M} ;{ }^{\$}: \mathrm{p}<0.05$ versus PHA/PMA stimulation with dexamethasone at concentrations of $10^{-6}-10^{-7} \mathrm{M}$, Kruskal-Wallis followed by Mann-Whitney analysis. Values are calculated as 100 - (cytokine expression with PHA/PMA and dexamethasone/cytokine expression with PHA/PMA only) $\times 100$.

(Ig)E-synthesis and the stimulation of proliferation of Th2 cells $[21,22]$. Indeed, clinical experiments suggest a sequential involvement of these cytokines, with IL-4 directing T-cells to a Th-2 phenotype, release IL-3, IL-5 and GM-CSF upon inhaled allergen stimulation, resulting in airway eosinophilia, and possibly airway hyperresponsiveness [23]. The data in the current study suggest that whilst the suppresion of these cytokines by CD4+ cells is likely to be an important mechanism underlying the therapeutic effect of corticosteroids in asthma, theophylline is likely to exert its anti-inflammatory actions via different mechanisms. These data also demonstrate that salbutamol has no significant effects on these cytokines.

In this study, it was decided to choose healthy subjects to avoid the effects of any previous drug treatment might have on the T-lymphocytes. In previous studies, no significant difference in the gene expression of the cytokines between normal control subjects and stable asthmatics was found, although the expression in acute severe asthmatics was increased $[7,8]$. These studies also found that steroid treatment resulted in a fall in the level of gene expression in subjects with acute severe disease, to a level similar to the current findings amongst normal subjects. Hence, the authors feel that the use of normal subjects in this experimental study is valid and that the steroid arm of this current study is acting as a positive control in demonstrating the effects of theophylline and salbutamol on the gene expression of these cytokines. Criticism may arise from the use of peripheral T-cells instead of cells derived from the lung. However, previous finding of increased cytokine gene expression in peripheral T-cells in acute asthma has also been confirmed by other researchers who studied inflammatory cells within the bronchial mucosa [24]. Hence, it is likely that peripheral blood T-cell cytokine gene expression may reflect the situation in the bronchial mucosa.

The therapeutic range of theophylline is usually taken as $10-20 \mu \mathrm{g} \cdot \mathrm{mL}^{-1}$ [25]. After $12 \mathrm{mg}$ dexamethasone $\cdot$ day $^{-1}$ is given intravenously or orally, plasma concentrations range $40-100 \mathrm{ng} \cdot \mathrm{mL}^{-1}$ [26]. Hence, these in vivo concentrations are covered by the range of concentrations used in the present study. The results show that at therapeutic concentrations, theophylline does not exert any significant effects on the cytokine gene expression of CD4+ cells. On the other hand, suppression of cytokine gene expression occurs even at low concentrations of dexamethasone.

Several clinical studies have shown that theophylline may exert its immunomodulatory effects by regulating the trafficking of T-lymphocytes rather than their activation. KIDNEY et al. [10] demonstrated that in asthmatics treated with long-term theophylline and high dose inhaled corticosteroids, the withdrawal of theophylline was accompanied by a worsening of asthma symptoms and its control, together with a reduction of CD4+ lymphocytes in peripheral blood and an increase of these cells in bronchial biopsies. These findings were complemented by another double-blind, placebo controlled study which demonstrated that treatment of atopic asthmatics with theophylline was accompanied by a significant reduction in

Table 4. - Percentage inhibition of cytokine messenger ribonucleic acid (mRNA) expression of CD4+ cells by salbutamol

\begin{tabular}{lcccccc}
\hline & \multicolumn{5}{c}{ Salbutamol concentration $\mathrm{M}\left(\mu \mathrm{g} \cdot \mathrm{mL}^{-1}\right)$} \\
\cline { 2 - 7 } & $10^{-4}$ & $10^{-5}$ & $10^{-6}$ & $10^{-7}$ & $10^{-8}$ & $10^{-9}$ \\
& $(58)$ & $(5.8)$ & $(0.58)$ & $(0.058)$ & $(0.0058)$ & $(0.00058)$ \\
\hline IL-3/GAPDH & $17.6 \pm 6.5$ & $0.6 \pm 15.0$ & $11.9 \pm 13.9$ & $2.9 \pm 11.8$ & $-14.8 \pm 18.9$ & $10.7 \pm 9.9$ \\
IL-4/GAPDH & $13.4 \pm 14.3$ & $-3.0 \pm 24.1$ & $11.2 \pm 6.8$ & $12.3 \pm 12.0$ & $-5.1 \pm 25.1$ & $10.3 \pm 17.1$ \\
IL-5/GAPDH & $-5.5 \pm 15.6$ & $-14.4 \pm 26.8$ & $13.3 \pm 10.8$ & $-8.5 \pm 13.8$ & $-20.7 \pm 27.8$ & $13.9 \pm 12.1$ \\
GM-CSF/GAPDH & $-1.9 \pm 20.9$ & $-20.0 \pm 19.4$ & $8.8 \pm 16.6$ & $-10.6 \pm 18.3$ & $14.6 \pm 12.0$ & $-11.2 \pm-11.1$ \\
IFN- $\alpha /$ GAPDH & $-17.0 \pm 16.4$ & $12.1 \pm 19.2$ & $-11.5 \pm 12.3$ & $-6.8 \pm 13.0$ & $-14.7 \pm 14.5$ & $-11.6 \pm 13.0$ \\
\hline
\end{tabular}

Data are mean \pm SEM. For definitions, see footnote to table 2. Salbutamol did not produce any significant suppression of gene expression of any of the cytokines at concentrations of $10^{-4}-10^{-9}$. Statistical analysis was Kruskal-Wallis followed by Mann-Whitney tests. Values are calculated as 100\% - (cytokine expression with PHA/PMA \& salbutamol/cytokine expression with PHA/PMA only $\times 100 \%$. 


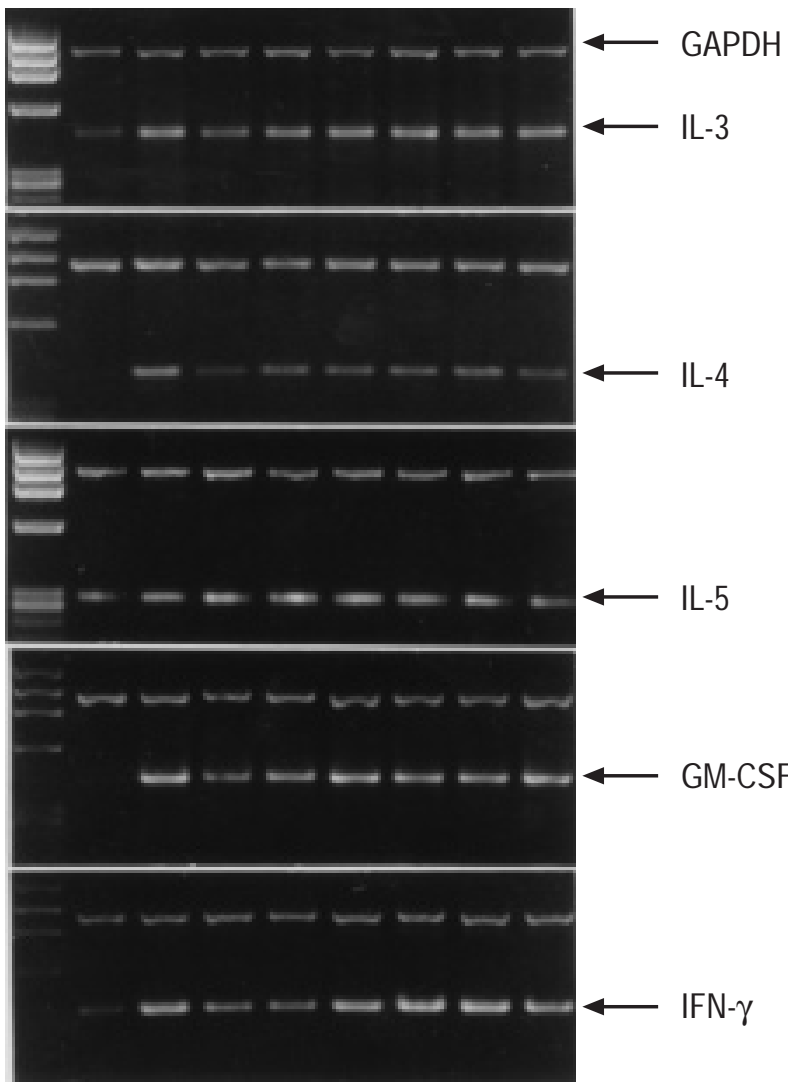

Fig. 1. - Agarose gel electrophoresis of polymerase chain reaction (PCR) products of reduced glyceraldehyde 3-phosphate dehydrogenase (GAPDH) and cytokine (interleukin (IL)-3, IL-4, IL-5, granulocytemacrophage colony-stimulating factor (GM-CSF) and interferon (IFN)$\gamma)$ messenger ribonucleic acid (mRNA) from CD4+ T-cells with decreasing concentrations of theophylline. Lane 1: Haemophilus aegyptius (Hae)III-digested $\Phi$ X174 deoxyribonucleic acid (DNA) size standards; 2: medium; 3: phorbol myristate acetate (PMA)/phytohaemogglutinin (PHA) alone; 4-9: PMA/PHA with $10^{-3}, 10^{-4}, 10^{-5}, 10^{-6}, 10^{-7}$ and $10^{-8} \mathrm{M}$ theophilline $\left(180-0.0018 \mu \mathrm{g} \cdot \mathrm{mL}^{-1}\right)$, respectively.

the number of CD4+ lymphocytes in bronchoalveolar lavage (BAL) fluid and a corresponding elevation of these cells in peripheral blood [27]. Moreover, the authors in the latter study [27] found that theophylline therapy appeared to be associated with a reduction in the absolute numbers of BAL CD4+ T-cells expressing activation markers but not a decrease in the proportion of these cells. In other words, the drug may have modulated the movement both of activated and nonactivated lung CD4+ Tcells rather than acting directly to inhibit the activated status of CD4+ cells. This hypothesis is consistent with the results of the present study.

A previous study of the effects of theophylline on mucosal inflammation in asthmatic airways utilizing bronchial biopsy results found that in patients with mild to moderately severe atopic asthma, treatment with theophylline resulted in a significant reduction of the number of cells containing IL-5 [15]. However, the cellular origins of these cells are not known. Both mast cells and eosinophils are capable of synthesizing IL-5 [28, 29] and theophylline may exert its cytokine inhibitory effects on them. Furthermore, some of the subjects in that study were receiving inhaled corticosteroids, making the interpretation of results difficult. The present utilized normal subjects so

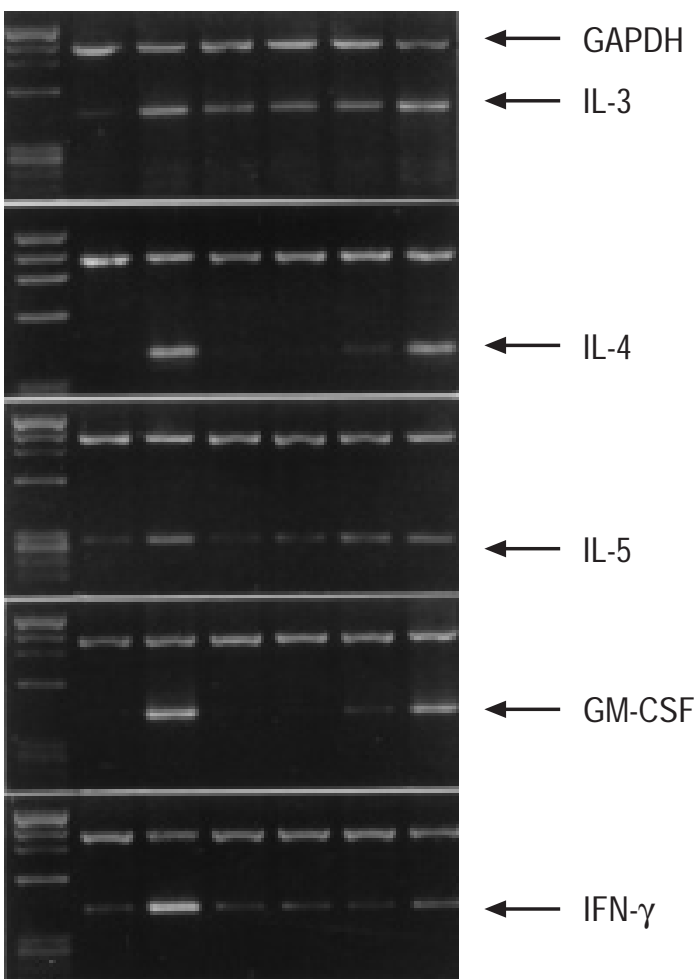

Fig. 2. - Agarose gel electrophoresis of polymerase chain reaction (PCR) products of GAPDH and cytokine (IL-3, IL-4, IL-5, GM-CSF and IFN- $\alpha$ ) mRNA from CD4+ T-cells with decreasing concentrations of dexamethasone. Lane 1: HaeIII-digested ФX174 DNA size standards; 2: medium; 3: phorbol myristate acetate (PMA)/phytohaemogglutinin (PHA) alone; 4-7: PMA/PHA with $10^{-6}, 10^{-7}, 10^{-8}$ and $10^{-9} \mathrm{M}$ dexamethasone $\left(390-0.39 \mathrm{ng} \cdot \mathrm{mL}^{-1}\right)$, respectively. For definitions, see legend to figure 1 .

that all subjects would be naïve to all anti-asthmatic medications. Based on these results, it would appear that theophylline does not have any inhibitory effects on cytokine production in $\mathrm{CD} 4+$ cells.

These studies together with the results of this study suggest that corticosteroids and theophylline probably act via different mechanisms to produce anti-inflammatory effects. This has important therapeutic implications as it suggests that these two agents would have additive effects. Studies have shown that high-dose inhaled corticosteroids may cause significant systemic effects, including the suppression of the pituitary-adrenal axis, decreased skin thickness, and enhanced bone absorption with reduced bone formation. Furthermore, even high doses of inhaled corticosteroids may not provide adequate asthma control, despite optimal compliance and technique $[30,31]$. The addition of a second drug that would improve control and at the same time act as a steroid-sparing agent is therefore highly desirable. Indeed, there are now at least four randomized, double-blind, controlled trials confirming that theophylline adds substantial clinical benefit to asthmatics treated with inhaled or systemic corticosteroids [10, 30-32].

Recent studies have suggested that regular $\beta$-agonist administration may increase airway inflammation and hyperresponsiveness to histamine and methacholine in asthmatic subjects [33]. The mechanism whereby this occurs remains unknown. The results of the present study 


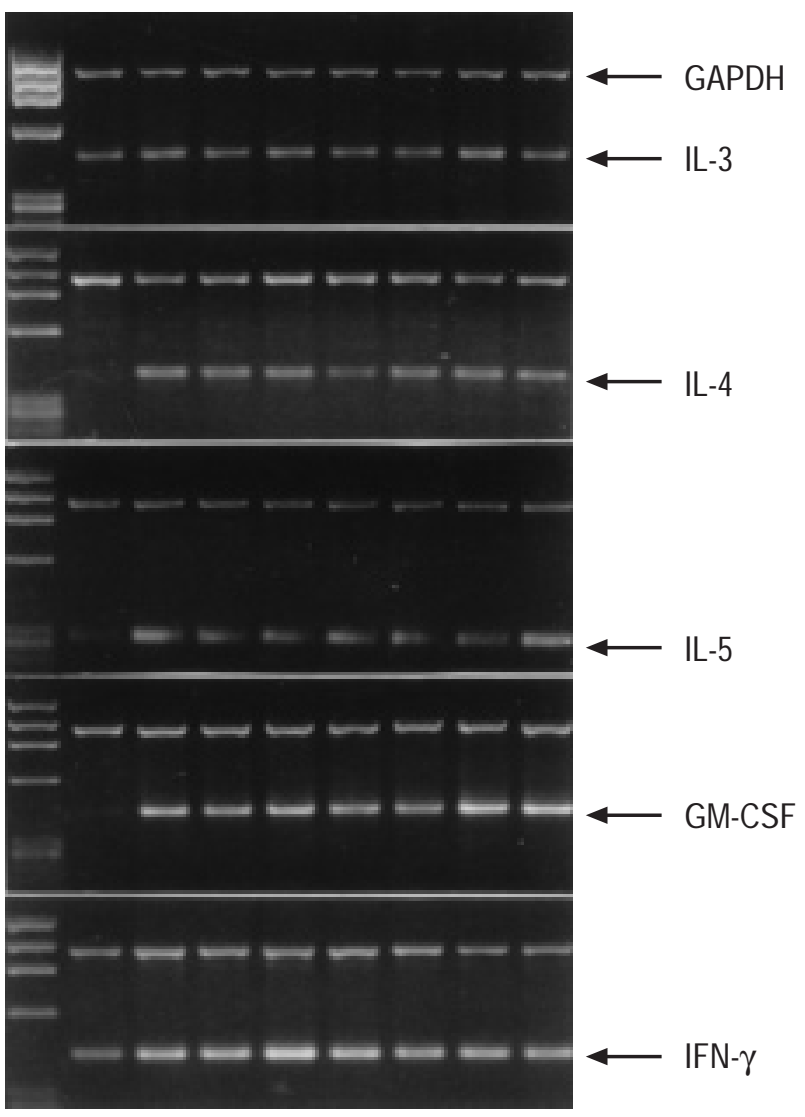

Fig. 3. - Agorose gel electrophoresis of polymerase chain reaction (PCR) products of GAPDH and cytokine (IL-3, IL-4, IL-5, GM-CSF and IFN- $\gamma$ ) mRNA from CD4+ T-cells with decreasing concentrations of salbutamol. Lane 1: HaeIII-digested $\Phi$ X174 DNA size standards; 2: medium; 3: phorbol myristate acetate (PMA)/phytohaemogglutinin (PHA) alone; 4-9: PMA/PHA with $10^{-4}, 10^{-5}, 10^{-6}, 10^{-7}, 10^{-8}$ and $10^{-9} \mathrm{M}$ salbutamol $\left(58-0.00058 \mu \mathrm{g} \cdot \mathrm{mL}^{-1}\right)$, respectively. For definitions, see legend to figure 1 .

demonstrate that if $\beta$-agonists do possess pro-inflammatory properties, these are unlikely to be related to their effects on cytokine production of CD4+ cells. Regular $\beta$ agonist administration may allow an increased allergen load to reach the airways by masking the allergen-induced early asthmatic response leading to the development of a late asthmatic response [34]. Alternatively, tachyphylaxis of $\beta$-receptors present on mast cells may result in destabilization causing these cells to release their inflammatory mediators more readily [35].

In conclusion, this study demonstrates that the suppression of cytokine gene expression in CD4+ T-cells does not occur at therapeutic concentrations of theophylline and salbutamol but is likely to be an important mechanism underlying the therapeutic effect of corticosteroids in asthma.

Acknowledgements. The authors thank I. Shum and P.K. Ma for their technical assistance.

\section{References}

1. Djukanovic R, Wilson JW, Britten KM, et al. Mucosal inflammation in asthma. Am Rev Respir Dis 1990; 142: 434-457.

2. Bousquet J, Chanez P, Lacoste JY, et al. Eosinophilic inflammation in asthma. N Engl J Med 1990; 323: 10331039.

3. Kay AB. T-cells, cytokines and asthma. $J R$ Coll Physicians Lond 1994; 28: 325-331.

4. Meijer RJ, Kerstjens HAM, Postma DS. Comparisons of guidelines and self-management plans in asthma. Eur Respir J 1997; 10: 1163-1172.

5. Okayama H, Fushimi T, Shimura S, Sasaki H, Shirato K. Glucocorticoids suppressed production and gene expression of interleukin-5 by peripheral blood mononuclear cells in atopic patients and normal subjects. J Allergy Clin Immunol 1994; 93: 1006-1012.

6. Bentley AM, Hamid Q, Robinson DS, et al. Prednisolone treatment in asthma: reduction in the numbers of eosinophils, T-cells, Tryptase-only positive mast cells, and modulation of IL-4, IL-5, and interferon-gamma cytokine gene expression within the bronchial mucosa. Am J Respir Crit Care Med 1996; 153: 551-556.

7. Lai CKW, Ho SS, Tang J, Chan CHS, Lai KN. Interleukin-5 (IL-5) messenger RNA expression in peripheral blood CD4+ cells in asthma. J Allergy Clin Immunol 1996; 97: 1320-1328.

8. Lai CKW, Ho SS, Chan CHS, Leung R, Lai KN. Gene expression of interleukin-3 and granulocyte macrophage colony-stimulating factor in circulating CD4+ T-cells in acute severe asthma. Clin and Exp Allergy 1996; 26: 138146.

9. Ward AJM, McKenniff M, Evans JM, Page CP, Costello JF. Theophylline - an immunomodulatory role in asthma? Am Rev Respir Dis 1993; 147: 518-523.

10. Kidney J, Dominguez M, Taylor PM, Rose M, Chung KF, Barnes PJ. Immunomodulation by theophylline in asthma: demonstration by withdrawal of therapy. Am J Respir Crit Care Med 1995; 151: 1907-1914.

11. Barnes PJ, Pauwels RA. Theophylline in asthma: time for reappraisal? Eur Respir J 1994; 7: 579-591.

12. Kita H, Abu-Ghazeleh RI, Gleich GJ, Abraham RT. Regulation of Ig-induced eosinophil degranulation by adenosine 3', 5'-cyclic monophosphate. J Immunol 1991; 146: 2712-2718.

13. Louis RE, Radermecker MR. Substance P-induced histamine release from human basophils, skin and lung fragments: effect of nedocromil sodium and theophylline. Int Arch Allergy Appl Immunol 1990; 92: 329-333.

14. Essayan DM, Huang S-K, Undem BJ, Kagey-Sobotka A, Lichtenstein LM. Modulation of antigen- and mitogeninduced proliferative responses of peripheral blood mononuclear cells by non-selective and isozyme selective cyclic nucleotide phosphodiesterase inhibitors. J Immunol 1994; 153: 3408-3416.

15. Djukanovic R, Finnerty JP, Lee C, Wilson S, Madden J, Holgate ST. The effects of theophylline on mucosal inflammation in asthmatic airways: biopsy results. Eur Respir J 1995; 8: 831-833.

16. Lai KN, Leung JCK, Li PKT, Larche M, Ritter MA. The effects of blockade of interleukin 2 receptors and interleukin 4 receptors on cytokine production. APMIS 1991; 99: 434-442.

17. Lai KN, Leung JCK, Li PKT, Lui SF. Cytokine production by peripheral blood mononuclear cells in IgA nephropathy. Clin Exp Immunol 1991; 85: 240-245.

18. Brenner CA, Tam AW, Nelson PA, et al. Message amplification phenotyping (MAPPing): a technique to simultaneously measure multiple mRNAs from small numbers of cells. BioTechniques 1989; 7: 1096-1103.

19. Lai KN, Leung JCK, Lai KB, Lai CKW. Effect of AntiDNA autoantibodies on the gene expression of interleukin 
8, transforming growth factor-b, and nitric oxide synthase in cultured endothelial cells. Scand J Rheumatol 1997; 26: 461-467.

20. Weller PF. Cytokine regulation of eosinophil function. Clin Immunol Immunopathol 1992; 62: S55-S59.

21. Del Prete GF, Maggi E, Parronchi P, Chretien I, Tiri A, Macchia D, et al. IL-4 is an essential co-factor for the IgE synthesis induced in vitro by human T-cell clones and their supernatants. J Immunol 1988; 140: 4193-4198.

22. Bruseelle GG, Kips JC, Tavernier JH, et al. Attenuation of allergic airway inflammation in IL-4 deficient mice. Clin Exp Allergy 1994; 24: 73-80.

23. Pauwels RA, Brusselle GG, Tournoy KG, Lambrecht BN, Kips JC. Cytokines and their receptors as therapeutic targets in asthma. Clin Exp Allergy 1998; 28: S1-S5.

24. Robinson DS, Ying S, Bentley AM, et al. Relationships among numbers of bronchoalveolar ravage cells expressing messenger ribonucleic acid for cytokines, asthma symptoms, and airway methacholine responsiveness in atopic asthma. J Allergy Clin Immunol 1993; 92: 397403.

25. Weinburger M. The pharmacology and therapeutic use of theophylline. J Allergy Clin Immunol 1984; 73: 525-540.

26. Duggan DE, Yeh KC, Matalia MS, Ditzler CA, McMahon FG. Bioavailability of oral dexamethasone. Clin Pharmacol Ther 1975; 18: 205-209.

27. Jaffar ZH, Sullivan P, Page C, Costello J. Low-dose theophylline modulates T-lymphocytes in allergen-challenged asthmatics. Eur Respir J 1996; 9: 456-462.

28. Broide DH, Paine MM, Firestein GF. Eosinophils express interleukin 5 and granulocyte colony-stimulating factor mRNA at sites of allergic inflammation in asthmatics. $J$ Clin Invest 1992; 90: 1414-1424.

29. Okayama Y, Semper A, Holgate ST, Church MK. Multiple cytokine mRNA expression in human mast cells stimulated via Fc epsilon RI. Int Arch Allergy Immunol 1995; 107: $158-159$.

30. Nassif EG, Weinberger M, Thompson R, Huntley W. The value of maintenance theophylline in steroid-dependent asthma. $N$ Engl J Med 1981; 304: 71.

31. Brenner M, Berkowitz R, Marshall N, Strunk RC. Need for theophylline in severe steroid-requiring asthmatics. Clin Allergy 1988; 18: 143.

32. Evans DJ, Taylor DA, Zetterstrom O, Chung FK, O'Connor BJ, Barnes PJ. A comparison of low-doser inhaled budesonide plus theophylline and high-dose inhaled budesonide for moderate asthma. $N$ Engl J Med 1997; 337: 1412.

33. Sears MR, Taylor DR, Print CG, et al. Regular inhaled beta-agonist treatment in bronchial asthma. Lancet 1990; 336: 1391-1396.

34. Lai CKW, Twentyman OP, Holgate ST. The effect of an increase in inhaled allergen dose after rimiterol hydrobromide on the occurrence and magnitude of the late asthmatic response and the associated change in non-specific bronchial responsiveness. Am Rev Respir Dis 1989; 140: 917-923.

35. O'Connor BJ, Aikman S, Barnes PJ. Tolerance to the nonbronchodilating effects of inhaled beta-2 agonists in asthma. N Eng J Med 1992; 327: 1204-1208. 